\title{
演題 B-1-920
}

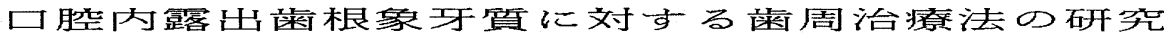
I . 歯周病罹患歯と健全歯の歯根象牙質への歯肉線維芽細胞の付着・増殖

北海道大学歯学部歯科保存学第 2 講座、"歯科薬理学講座

○根岸 淳、加藤 熙、松本 章*

A Study of Periodontal Treatments on Intra-orally Exposed Root Dentin

I. Attachment and Growth of Human Gingival Fibroblasts on Periodontitis-affected and Healthy Root Dentin Department of Periodontology and Endodontology, "Department of Pharmacology,

Hokkaido University School of Dentistry

OJun NEGISHI, Hiroshi KATO, Akira MATSUMOTO*

キーワード : 歯根象牙質、線維芽細胞

\section{[目的]}

近年、歯根面に繰り返しスケーリングやルートプレー ニングを受け、象牙質が口腔内に露出し、プラークが付 着する症例が増加している。しかし、露出歯根象牙質に 対する新付着を目的とした歯周治療法は、露出セメント 質に対するあのに比べ、ほとんど研究されておらず、適 切な治療法を検討する必要がある。スケーリング・ルー トプレーニングによる治療法を検討するとき、歯周病に 䍜患した歯の象牙質と健全歯の象牙質では、同程度に表 層を処置しても歯周組織が付着する様相に差が生じる可 能性がある。そこで本研究は、歯周病䍜患歯と健全歯の 歯根象牙質への線維芽細胞の付着の様相を比較検討する 目的で、双方の歯根象牙質上でヒト歯肉線維芽細胞を培 養し、付着・増殖細胞数を計測するととすに、歯根象牙 質の病理組織学的観察を行った。

\section{「材料および方法〕}

1. 試験片の作製

矯正治療のため抜去した健全歯（A群）と、根面及び 歯冠部にう蝕や充填物がなく高度の歯周病のため抜去さ れた歯（P群）を用い、根面を約 $1 \mathrm{~mm}$ 削除して象牙質を 露出させ、 $4 \times 4 \times 1 \mathrm{~mm}$ の試験片を切り出し、過去に治 療処置を受けたことを想定して表面を超音波スケーリン グした。

2. 細胞培養と評価

ヒトの健康な辺縁歯肉から初代培養、継代して得られ た線維牙細胞を実験に使用した。各群10個ずつの象牙質 試験片をオートクレーブ滅菌後、直径 $35 \mathrm{~mm}$ のペトリディ ッシュに静置し、細胞浮遊液（ $1 \times 10^{5}$ 個/m1、10\%FBS $+M E M$ 培地）を分注し、96時間培養した。培養後、試料 を固定染色し、根面上に付着増殖した線維芽細胞の数を 光学顕微鏡 $(\times 100)$ で計測した。

3 . 病理組織学的観察

$\mathrm{A}$ 群と $\mathrm{P}$ 群各10個の試験片をギ酸で脱灰し、Brown一 Brenn 染色して、プラークの付着状態と象牙細管内の細 菌の侵入状況の観察を行った。

[結果]

1. 付着・増殖した線維芽細胞の観察と細胞数の測定結 果

$\mathrm{A}$ 群、P群ともたくさんの線維芽細胞が試験片に高密
度に付着し、よく伸張している像が観察された。A群の 付着細胞数は平均 $22.1 \pm 8.4$ 個、P 群は18.8土7.9個で、 P 群のほうがやや低い值を示したが、Wi1coxon検定にお いて、両群の間に統計学的有意差はなかった（図）。

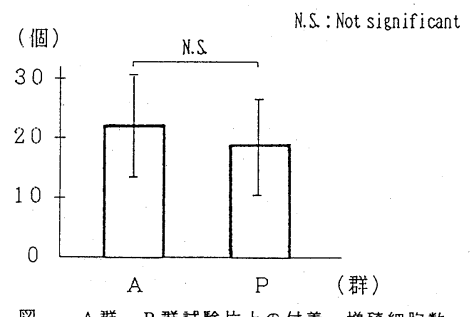

2.病理組織学的観察の結果

$\mathrm{A}$ 群の全てとP群のほとんどの標本では、プラークの 付着お上び象牙細管への細菌の侵入はみられなかった。 しかし、P群では、10個の試験片中 2 個の組織標本のご く一部に、象牙細管の深部にまで細菌が侵入している像 が観察された。

[考察]

$\mathrm{A}$ 群、P 群の付着・增殖細胞数および病理所見より、 高度な歯周病罹患歯の大部分の例では、表層から $1 \mathrm{~mm} の$ 象牙質には健全歯と比較して差はみられない。すなわち、 セメント筫が存在している場合、口腔内に根が露出して あ、それに伴う変化は深部の象牙質までは及んでいない 場合が大部分である。しかし一部の例では象牙細管内に 細菌がみられたことから、セメント質が存在しても内部 の象牙質に細胞の付着を阻害する変化が起こっている可 能性すあると思われる。 


\title{
演題 B-2-930
}

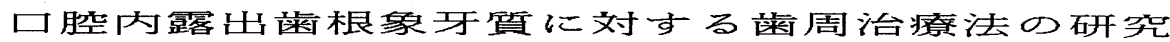

II. 実験的に口腔内に露出させた歯根象牙質に対する歯周治療法の検討

\author{
北海道大学歯学部歯科保存学第 2 講座 \\ ○根岸 淳、川浪雅光、佃 宣和、松本敦至、伊藤 豊、岡 秀博、田中直人、堤洋比古、加藤 照 \\ A Study of Periodontal Treatments on Exposed Root Dentin \\ II. Investigations of Periodontal Treatments on Experimentally Exposed Root Dentin \\ Department of Periodontology and Endodontology, Hokkaido University School of Dentistry \\ OJun NEGISHI, Masamitsu KaWANAMI, Nobukazu TSUKUDA, Atsushi MATSUMOTO, Yutaka ITO. \\ Hidehiro OKA, Naohi to TANAKA, Hirohiko TSUTSUMI, Hiroshi KATO
}
キーワード : 歯根象牙質、スケーリング、ルートプレー ニング、線維芽細胞
[目的]

本研究は、歯周疾患の進行や歯周治療により口腔内に 露出した歯根象牙質に歯周組織の新付着を形成させる場 合の適切な治療法を知る目的で、高度の歯周病罹患によ り抜去された歯を被験歯として用い、超音波スケーリン グを行った歯根象牙質を実験的に一定期間口腔内に露出 させた後、象牙質面にキュレットタイプスケーラーを用 いた 2 種類の治療処置を行い、細胞培養系と病理組織学 的観察により比較検討した。

\section{[材料および方法］}

1. 試験片の作製

根面及び歯冠部にう蝕や充填物がなく、高度の歯周病 のため抜去された歯を無作為に選び、根面を約 $1 \mathrm{~mm}$ 削除 して象牙質を露出させ、 $4 \times 4 \times 1 \mathrm{~mm}$ の試験片を切り出 し、表面を超音波スケーリングした。

2 . 試験片の口腔内への露出

試験片を、歯肉上皮に囲まれた歯周ポヶット内を想定 した環境内におくために、上顎レジン床装置の粘膜面に 埋め込み、6人の被験者の口腔内に露出させた。口腔内 露出期間は $0 、 1 、 2 、 4$ 週間とした。

3 . 試験片の分類と治療処置

口腔内露出期間終了後試験片を治療処置の内容により $\mathrm{B}$ 群（無処置）、C 群（表層を一層スケーリング・ルー トプレーニング）、D群（硬く滑沢な象牙質面が得られ るまで徹底的にスケーリング・ルートプレーニング）の 3 群に分けた。この分類に露出期間による分類を組み合 わせ、例えば B 群で口腔内に露出させないむのは B 0 群、 1 週のあのはB 1 群、2 週のむのはB2群、4 週のむの は B 4群とした。他の群も同じように分類し、全部で12 群とした。

4. 試験片上での細胞培養と付着・増殖細胞数の測定

ヒトの健康な辺縁歯肉から初代培養、継代して得られ た線維芽細胞を実験に使用した。各群10個ずつの象牙質 試験片をオートクレーブ滅菌後、直径 $35 \mathrm{~mm}$ のペトリディ ッシュに静置し、細胞浮遊液 $\left(1 \times 10^{5}\right.$ 個/ml、1.0\% FBS +MEM 培地) を分注し、96時間培養した。培養後、試料 を固定染色し、根面上に付着、増殖した線維芽細胞の数 を光学顕微鏡 $(\times 100)$ で計測した。

5 . 病理組織学的観察

$\mathrm{A}$ 群と $\mathrm{P}$ 群各10個の試験片をギ酸で脱灰し、Brown-
Brenn 染色して、プラークの付着状態と象牙細管内の細 菌の侵入状態の観察を行った。

[結果]

・B 1、B 2、B 4 群では、象牙質表面にプラークが付着 し、付着した線維芽細胞はほとんどみられなかった。 4 週間経過すると、細菌が象牙細管内に侵入していく のあ認められた。

・C 0 群に比べ、C 1、C 2、C 4 群は付着細胞数が有意に 少なかった。 C 1 群では、D1群とある程度類似した 付着・増殖細胞数を示したが、C 2、C 4 群では著しく 少なかった。病理所見では、全試験片とも象牙質表面 の一部にプラークの残存が認められた。

・D 1、D2、D4 群は、付着細胞数は D 0群に比べ少な かったが、C 1、C 2、C 4 群と比べると良好であった。 病理所見では、プラークの残存は認められなかった。 しかし C 4 群の極めてごく一部では、口腔内露出によ り侵入したと思われる細菌が象牙質表層に残存してい るのが観察された。

\section{[考察]}

象牙質の口腔内露出が 1 週間以内の場合には、象牙質 表面の污染がまだ浅く、表層一層のみのスケーリング . ルートプレーニングですある程度の効果が得られるが、 一週間以上口腔内に露出した歯根象牙質に歯周組織の新 付着を起こすためには、表層一層のみのスケーリング・ ルートプレーニングでは不確実で、徹底したスケーリン グ・ルートプレーニングを行う必要があると思われた。 しかし、徹底したスケーリング・ルートプレーニングを 行うと、術後の知覚過敏を引き起こす危険性を大きくし てしまう問題点が考えられ、より適切な治療法を総合的 に開発、検討していくことが今後の課題であると思われ る。 
露出セメント質へのL P S の浸透について 免疫組織化学的検索

昭和大学歯学部歯周治療学教室、口腔病理学教室 * 、口哚細菌学教室 **、 昭和大学薬学部微生物薬品化学教室***

○須田玲子、茂手木義男、小林誠、宮下 元、長谷川紘司、立川哲彦・ 、

吉木周作 * 、後藤延一**、真下順一***、河西信彦***

Penetration of LPS into the exposed cementum

Immuno-histochemical observations

Dept. of Periodontics, Dept. of 0ral Pathology*. Dept. of Oral Microbiology**, School of Dentistry. Showa Univ.. Dept. of Microbial Chemistry***, School of Pharmaceutical Sciences. Showa Univ.

OReiko SUDA, Yoshio MOTEGI, Makoto KOBAYASHI, Hajime MIYASHITA,

Kohji HASEGAWA, Tetsuhiko TACHIKAWA*, Shusaku YOSHIKI*, Nobuichi goto**, Jun-ichi MASHIM0***, Nobuhiko KASAI***

キーワード：L P S、露出セメント質、Bacteroides gingivalis

\section{【緒言】}

歯周病の原因菌と考えられている多くの細菌に は、内毒素 (L P S ) が存在し、样々な免疫反応を 惹起させるといわれている。その結果として、 L P S は歯周組織に、骨吸収や、線維芽細胞に対す る為害性を有するなど、多くの報告がある。しかし ながら、歯周ポケット内での L P S の局在部位や、

L P S が歯周疾患の進行と歯周治㞠後の治瘾にどの ような影響を及ぼすのかについては諸説があり、不 明瞭な点が多い。そこで、今回、我々は、 Bacteroides gingivalis (B.g.)のL P S の、露出セ メント質における局在について、免疫組織化学的検 索を行った。

\section{【材料と方法】}

1.LPS 抗体の精製

B.g. \#381 をへミン、メナジオン添加血液寒天培 地で一次培養し、次に、液体培地にて二次培養し た。培養後、培養液を $10,000 \mathrm{rpm} 20$ 分間遠心分離 し、沈激を $0.95 \% \mathrm{NaCl}$ 溶液で洗浄後、さらに遠心分 離して、集菌し、凍結乾燥した。凍結乾燥菌 $20 \mathrm{~g}$ か ら、Westphal等"のフェノールーウォーター法に よってLPSを抽出した。透析、遠心分離 (4.500 r pm、20分) 、濃縮後、凍結乾燥し、これを粗製 L P S とした。この粗製 L P S を超遠心 $(40,000$ rpm、4時間）にかけ、凍結乾燥したものを精製 L P S とした。精製 L P S をcomplete Freund's adjuvantと混合しエマージョンとしたものを、家鬼 の背部に 2 週おきに 3 回、皮下注射して免疫を行っ た。最終免疫後 2 週目に、抗体産生を確認、全血の 採取を行った。採取した抗血清より、IgG 分画を抽 出した。

\section{2. 被験歯の準備}

被験歯には、過去において歯周治療の既往がな く、高度歯周疾患に䍜患し保存不可能と判断されて 抜歯した歯を使用した。対照歯には、矯正治療上便 宜抜去された小四歯、及び埋伏智歯を使用した。抜 歯後、PLP 固定液、または1\%ピクリン酸固定液にて 24 時間固定し、歯を細分、通法に従い、脱水、

L R white に包埋した。その後、ガラスナイフにて $1 \mu$ 切片を作製した。

\section{3. 免疫染色}

一次抗体にはウサギ抗 L P S 血清を使用し、二次 抗体は、FITC標識ヤギ抗ウサギIgG、ならびに Streptoavidin-biotin標識ヤギ抗ウサギIgG を使用 して、各切片に対し間接法による免疫染色を行い、

顕微鏡下にて、L P S の局在を観察した。

\section{【結果】}

1. 凍結乾燥菌 $20 \mathrm{~g}$ より、約 $200 \mathrm{mg}$ の精製 $\mathrm{L}, \mathrm{P} \mathrm{S}$ を得 た。

2.露出セメント質において、B.g.のL P S はセメン 卜質表層にとどまっているものが多かった。 
三次元培養におけるヒ卜歯周組織由来細胞の細胞增殖及び分化調節について 神奈川歯科大学口腔生化学教室

○川村太助、安伸浩、今井喜良、川瀬俊夫、斎藤 滋

Regulation of the Proliferation and Differentiation of Cells Derived from Human Periodontium in Three Dimentional Culture System Department of 0 ral Biochemistry. Kanagawa Dental College

OT. Kawamura, N. Yasu, K. Imai, T. Kawase and S. Saito

キーワード：ヒト歯根膜線維芽細胞、ゲル内培養、 ゲル収縮、 A L P a s e

\section{【目的】}

結合織系の細胞は、主要な基質成分であるCollagen Matrixに包埋されている。そこで、invivoにより近 い環境での細胞の性質を調べる手段として、Collagen gel内における 3 次元的な培養法が検討されている。

先の学会で、我々は、gel収縮によるヒト歯根膜か ら得られた線維芽細胞 (Human Periodontal Ligament Fibroblast：HPLF) の性質を調べる一助としてコラー ゲンを用いた 3 次元培養を応用し、増殖ならびに分化 への影響について報告してきた。

そこで今回は、HPLFを用い、ge 1内培養と通常の 2 次元培養との相違、gel cutkよって引き起こされる g e 1の収縮によるHPLFの応答を調べ、HPLFの性質、特 に細胞增殖及び分化調節に及ぼす影㸷について検討し た。

\section{【方法】}

\section{1. 細胞培養}

ヒト歯根膜は、1 $0 \sim 12$ 才の矯正治療時に抜去し た下顎第 1 小臼歯より採取し、Kawase et al.の方法 (Adv. Dent. Res. , 1988) によりヒト歯根膜由来の線維芽 細胞(HPLF)を得た。そして、3 $37^{\circ} \mathrm{C} 、 5 \% \mathrm{CO}_{2}+95 \%$ airの 条件下で継代を続けた。本実験において、6〜8passagesの HPLFを用いた。

\section{Collagen gel 内培養}

Collagen gelは以下のようにして作製した。細胞を 0. 25\%トリプジを含むPBS (-) (phosphate-buffered saline, pH7.4)で処理し、水冷下で市販のCollagen溶液 (Cellmatrix TypeI-A:豚健由来酸可溶性 Type I Collagen, 0.3\%, pH3.0, 新田ゼ ラチy社) に再構成用緩衝液 (2. $2 \% \mathrm{NaHCO}_{3}$ および $200 \mathrm{mMHEPES}$ を含む $0.05 \% \mathrm{NaOH}$ 溶 液) と $5 \%$ ウシ胎児血清 (FCS, F 1 ow社) 含む 5 倍濃度の Dulbecco's modified Eagle's medium (DMEM，日水製薬) を7:1:2の比率で加え、 $5.0 \times 10^{4} / \mathrm{ml}$ の密度になるよう 細胞を㲘濁させた。それを24petri multi well(住友へ” ークラ(1社)にinoculateし、 $\mathrm{CO}_{2}$ incubator内で gel化さ せた後、DMEMを重層して培養を行なった。gel cutは、 culturewellとgelの間に切込みを入れ浮遊させた。

細胞の形態は、位相差顕微鏡により観察した。

\section{ALPase活性の测定}

ALPase 活性测定は、p-nitrophenyl phosphateを基 質として测定した。 また、cell側、matrix側のALPase の異同を検討するため、gelをcollagenase処理して分 画し、電気泳動による活性染色及びALPaseのKinetics も調べた。また細胞增殖は、DNA 量、protein 量の変 化から求めた。

\section{【結果および考察】}

HPLFは、ost eoblasticな性格を持つことが報告され ていることから、分化の指標として、ALPaseの活性の 変動を調べてみたところ、gel内培養ではP1 astic we11（2次元）での培養に比べ著明に低值を示した. その際、ALPaseの局在を調べてみると、細胞とコラー ゲンマトリックスのそれぞれにALPase活性が認められ、 matrix中への活性の放出が示唆された。しかし、gel cutによるALPase活性の差異は認められなかった。 gel内培養下の細胞をcollagenase処理で回収して、 通常の二次元で recultureした場合、cutの有無に関わ らず細胞增殖には変化がなくgel cutによる増殖の抑制 は一過性であることが示された。しかし、gel cut群で のみALP活性の発現は、遅れていた。細胞の增殖に関し ては、Rat calvariaからcollagenase処理で得た Rat osteoblastic cells(ROB)についても同じことがいえる ことであるが、ALPase活性の発現からながめると、 ROBではgel内培養でやや抑制されるすのの、gel cutK よって活性が增加したのに比べ、HPLFではgel内培養が より強い抑制がみられgel cutによる活性の六進は認め られなかった。

以上のことから、HPLFは通常の 2 次元培養では高い ALPase活性を示すが、gel内培養系では、ALP活性の発 現の抑制がみられた。これはHPLFの細胞環境の変化に 対する特徵的な応答性を知るための興味ある実験系と 考えられる。

\section{【文献】}

1. E. Bell (1979) Proc.Natl.Acad. Sci USA 76:1274-

2. K. G. Murphy et al. (1986) J. Period. Res. 4:342- 
$\mathrm{T} G \mathrm{~F}-\beta$ およびE G F が培養ヒト歯根膜細胞のアルカリホスファターゼ活性

に及ぼす影響について

日本大学歯学部生化学教室

○大島光宏、桑田文幸、大塚吉兵衛、鈴木貫太郎

Effects of TGF- $\beta$ and EGF on Alkaline Phosphatase Activities of Cultured Human Periodontal Ligament Cells

Department of Biochemistry, Nihon University School of Dentistry

O Mitsuhiro OHSHIMA, Fumiyuki KUWATA, Kichibee OTSUKA, and Kantaro SUZUKI

キーワード：アルカリホスファターゼ、T G F - $\beta$ 、 E G F

\section{[目的]}

TGF- $\beta$ および EGF が、歯根膜細胞の石灰化能の 指標とされているアルカリホスファターゼ活性に影 響を及ぼすかどうかを調べること。

\section{[材料および方法］}

OHSHIMA ら（1988）の方法で、同一歯加ら得た培 趇七卜歯根膜細胞と画肉線維芽細胞とを 4 対用いた。 第 6 ないし第 7 継代目の両細胞を 96 穴プレート に $10 \%$ FBS を添加した $\alpha$-MEM 培地を用いて播き、 4 日後に $1 \%$ FBS と各種濃度の TGF- $\beta$ あるいは EGF を含む培地と交換し、更に4日間培養を行なっ たものをアルカリホスファターゼ活性測定のための 試料とした。アルカリホスファターゼ活性の測定は OHSHIMAら（1988）のマイクロタイターアッセイに準 じて行った。また、DNA 量は Hoechst 33342 を用い た蛍光法で求め、単位細胞数当たりの䣼素活性值を 算出してTGF- $\beta$ および EGF の効果を調べた。

\section{[結果]}

両細胞のアルカリホスファターゼ活性値とも TGF - $\beta$ の添加灌度に依存して上昇し、0.2 または $1 \mathrm{ng}$ /m1でピークに達したが $5 \mathrm{ng} / \mathrm{ml}$ では逆に隇少がみ られた。一方、EGF の添加では、摆度依存的にアル カリホスファターゼ活性值が減少した。また、歯肉 線維芽細胞のアルカリホスファターゼ活性值は、菌 根膜細胞の1/2〜1/3程度であった。細胞增殖に関し ては、両細胞ともに TGF- $\beta$ 、EGF の濃度依存的であ りその効果は TGF- $\beta$ の方が大きかった。

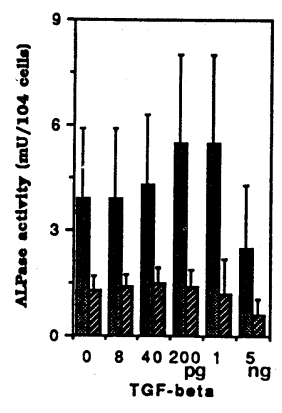

TGF- $\beta$ の影響

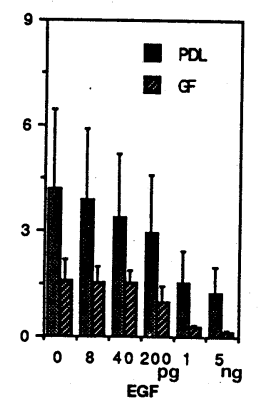

EGF の影響

\section{[考察]}

歯根膜細胞は、新生セメント質形成に関与するこ とが示唆されるなど、骨芽細胞と一部類似した性質 をもつことが報告されている。このことから、骨吸 収を抑制したり、未分化な間葉細胞を骨芽細胞に分 化させる因子のひとつとして考えられている TGF- $\beta$ や、歯の萌出および骨代謝に関与すると報告されて いる EGF が、歯根膜細胞の石灰化能の指標とされて いる細胞内アルカリホスファターゼ活性に影響を及 ぼすのではないかと考光、今回の実験を企図した。 その結果、TGF- $\beta$ 㹥両細胞のアルカリホスファター ゼ活性に $1 \mathrm{ng} / \mathrm{ml}$ 以下の濃度では促進的に、5 $\mathrm{ng} /$ m1の高濃度ではやや抑制的に働いたことから、この 因子は歯根膜細胞の石灰化能に関して両面性の効果 をむつことが示唆された。EGF は両細胞のアルカリ ホスファターゼ活性を濃度依存的に抑制したこと加 ら、この因子は歯根膜細胞の石灰化能に関して抑制 的に作用するのではないかということが示唆された。

\section{[結論]}

TGF- $\beta$ は $1 \mathrm{ng} / \mathrm{ml}$ までの濃度で蒌根膜細胞のア ルカリホスファターゼ活性を促進させたが、EGF は $5 \mathrm{ng} / \mathrm{m} 1$ まで濃度依存的にその活性を隇少させた。 
In Vitroにおける食菌多形核白血球の歯肉線維芽細胞傷害性について 日本歯科大学新潟歯学部口腔細菌学教室

○鈴木安里、葛城啓彰、加藤千穂美、斎藤和子

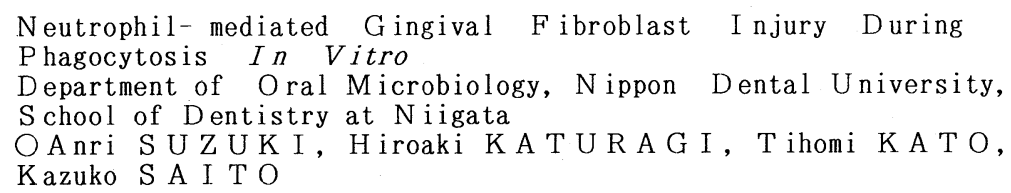

キーワード：歯肉線維芽細胞傷害、末梢血多形核白血 球 (PMN)、食菌作用

目的

A. viscosus, P.gingivalis の食菌を介して、P MNが歯肉線維芽細胞に傷害的に働くことを検索し、 その傷害性物質を解明することを目的とする。

\section{材料と方法}

1. 材料

正常ヒト歯肉線維芽細胞（G in-1, A T C C C R L 1.292 ), 健常者末梢血多形核白血球, 供試菌 Actinomyces viscosus N I A H 1010 ( 1 . 0 ) Porphyromonas gingivalis 381 ( F.g)

2. 方法

1 ）細胞傷害性の測定

96 穴マイクロタイタープレートに接種され ${ }^{51} \mathrm{Cr}$ 標識された $\mathrm{G}$ in- 1 上に、細胞比が Gin-1 : P MN= $1: 15, \mathrm{PMN}:$ 菌=1：100となるように、P $\mathrm{MN}$ と菌を加えた。一定時間のインキュベーションの 後、全放射線活性に対する反応液上清に放出された放 射線活性の割合を細胞融解率として測定した。また、 全付着細胞放射線活性に対するウェル底面から剥離し た、あるいは軽いすすぎによって剥離してしまう細胞 の放射線活性の割合を細胞剝離率として測定した。

\section{2 ）傷害抑制実験}

傷害測定系に、superoxide dismutase, catalase, $\alpha-1$-antitrypsin, 血清を添加し、細胞傷害の抑制の 有無を観察する。

\section{結果}

1. 食菌 P MNによる Gin-1 の傷害発現

細胞融解率は、A.v，P.gのどちらを用いた場合 でも、90 分までの測定では $5 \%$ を越えないごくわず かな值であった。一方細胞剥離率は、A.V を用いた
た場合、菌のみ、P MNのみではコントロールとほと んど差がなかったが、食菌系において 1 時間で 89 . 0 $9 \%$ に達し、この值は反応時間や $\mathrm{G}$ in-1 1 に対する $\mathrm{PMN}$ 数、菌数の増加に伴い上异した。これに対し、 P. $g$ は食菌系において 1 時間で $50.53 \%$ 達し たが、菌のみでも $53.59 \%$ の剥離率がみられた。

2. 傷害抑制

単層からの細胞の剝離は、 $A . v, P . g$ 両菌におい て $\alpha$-1-antitrypsinとヒト血清によって $80 \sim 98$ \%まで抑制されたが、活性酸素のスカベンジャーによ る抑制はみられなかった。

考察

炎症局所における多形核白血球は、食菌作用により 生体防御反応に貢献する反面、その放出産物によって 周囲組織に傷害性に働くといわれている。In Vitro における $A . v$ 食菌 P M N G G in- 1 剥離の誘発から 、歯肉溝部炎症に対する食菌白血球の細胞傷害性の関 与が考えられる。P.g において、菌のみの系でも剥 離がおこり、食菌系のものと差がなかったのは、菌自 体のトリプシン様活性が高く、食菌されにくいことに よるのかもしれない。抑制実験の結果から、主な傷害 性物質はプロテアーゼ酵素であると考えられる。血清 の剝離抑制作用は、 $\alpha-1$-antitrypsinや血墏ファイブ ロネクチンの存在によるものと考えられる。

結論

1. A. $v$ 食菌 P MNにより、 Gin- 1 の傷害が誘発 され、この傷害は 90 分までの反応では細胞融解を伴 わない細胞の剥離として観察された。

2. 剝離は $\alpha-1$-antitrypsin、血清により抑制さ れ、主な傷害性物質が P MNのプロテアーゼ酵素であ ることが示唆された。

3.P.g は菌のみで $\mathrm{G}$ in- 1 を剥離させた。 
演題 B-7-1020

白血球によるヒト歯周組織由来線維芽細胞に対する細胞傷害性について

神奈川歯科大学保存学教室第 2 講座、口胿生化学教室*

○出口眞二、堀俊雄、川瀬俊夫*、斎藤 滋*

PMNs Mediated Damage to Human Periodontium delived Fibroblast-1ike Ce1ls Department of Periodontology and Oral Biochemistry*, Kanagawa Dental College

O Shinji Deguchi, Toshio Hori, Toshio Kawase*, Shigeru Saito*

キーワード：細胞傷害性試験、ヒト歯根膜線維芽細胞

ヒト歯肉腺維芽細胞、ヒト末梢血多形核白血球

$<$ 目的 $>$

多形核白血球 (PMNs) は健康な歯肉溝あるいは辺縁性 歯周炎におけるポケット淩出液中に多数存在し、歯周 病原菌の侵襲に対し生体防御としての重要な役割を担 っている。PMNsは防御的役割と同時に炎症局所におい て組織傷害性に㗢くと考えられている。現在に至るま でヒト歯根膜由来腺維芽細胞 (HPLF) に対しLPS と FMLP で同時刺激したPMNsを作用させ、蛍光二重染色法によ り細胞傷害性を証明してきた。さらに、今回はヒト歯 肉由来腺維芽細胞 (HGF) に対しHPLFと同様に、細胞傷 害性について検索するのと同時に、細胞傷害発生にお いてPMNsのtarget cellsへの粘着の重要性について検 索した。

く材料および方法 >

\section{1. 細胞培養}

HPLFはKawase et al. (Adv. Dent Res 1988) の方法 で得、HGF は晚期残存の乳前歯抜去時の内斜切開によ り得られた健康な歯肉組織をHPLFの確立と同様に組織 より outgrowth してきた細胞を継代し実験に供した。 細胞は $2.0 \times 10^{4}$ cells/each well of 24 multi well plate の細胞密度で thermanox coverslip 上に接種し $37^{\circ} \mathrm{C}, 5 \% \mathrm{CO}_{2}$ 下にて培養した。6 日後には confluent monolayer ( $1 \times 10^{5}$ cells $/$ well) を得、細胞傷害性試 験に使用した。

\section{PMNsの調整}

健常人からへパリン (25 unit/ml 血液) 加新鮮脈血 を採取し、Ficol1-Hypaque溶液に重層し比重心法によ り分離後、低張食塩水にて赤血球を除去純度 $95 \%$ 以上 のPMNs溶液を実験に供した。

3.細胞傷害性の測定

Coverslip 上のconfluent monolayer の約 $1 \times 10^{5}$ HPLF cells/well に対し、10倍の $1 \times 10^{6}$ PMNsを1m1の
D-MEM に懸濁させ添加し、PMNs刺激には最終濃度とし て $1000 \mathrm{ng} / \mathrm{ml}$ のLPS, $10^{-6} \mathrm{M}$ FMLPを同時に添加し $5 \% \mathrm{CO}_{2}$ 気相下にて 3時間培した。fluorescein diacetate (F DA）と propidium iodide (PI)により二重染色し、細 胞傷害率を算出した。

4. Target cel1sへのPMNs粘着の阻止

24 multi well 中のthermanox coverslip 上の確立 されたconfluent monolayer 上にMILLICELL-HA, 0.45 $\mu \mathrm{m}$ Culture Plate Insert,12 diameterを静置後、PM Ns溶液をMILLICELL-HA内に注入しPMNsの刺激剂を添加 し細胞傷害性試験を行った。

<結果 $>1$. 細胞傷害率

HPLFとHGF においてLPS+FMLP (L+F) 添加群、PMNs (N ) 無刺激群、PMNsをLPS で刺激した群:N+L、PMNsをFM LPで刺激した群:N+F、PMNsをLPS, FMLPで同時刺激した 群: $\mathrm{N}+\mathrm{L}+\mathrm{F} に つ い て の$ 細胞傷害率はHPLFと同様にHGF に おいてもPMNs無添加群 $(\mathrm{L}+\mathrm{F})$ は $0.1 \pm 0.1 \%$ と最も低い 値を示した。最大の細胞傷害率を示したのは、HPLF, H $\mathrm{GF}$ 共に $\mathrm{N}+\mathrm{L}+\mathrm{F}$ 群で6.0 $2.8,5.5 \pm 1.7 \%$ 、、他の群 と比較し有意に高い値を示した。

2. Target cellsへの PMNs 粘着阻止効果

HPLF, HGF共にN+L+F 群について MILLICELL-HA を使 用し、細胞傷害発生に対するPMNsのtarget cells粘着 の重要性について検索した結果、 $\mathrm{N}+\mathrm{L}+\mathrm{F}$ 群と比較し細 胞傷害率はやや低下を示すものの、明らかな細胞傷害 率を示す結果が認められた。

〈結論および考察〉

HPLF, HGFにPMNsをLPS, FMLPで同時刺激することによ り、両細胞共に他の群より有意に高い値を示し、PMNs のtarget cellsへの粘着が起こらなくても細胞傷害は 惹起された。このことは、HPLFへのPMNsの粘着は刺激 因子により異なり、PMNsの粘着数と細胞傷害率が相関 を示した以前の結果と考え合わせてもPMNsは高い細胞 傷害因子を発生するものと思われる。 
培養ヒト歯根膜細胞および歯肉線維芽細胞のコラゲナーゼインヒビターに対する 熱・酵素・薬剂処理の影響について

日本大学歯学部生化学教室

○笹井義宣、大島光宏、桑田文幸、鈴木直人、大塚吉兵衛、鈴木貫太郎 Biochemical Properties of collagenase inhibitors in cultured human Periodontal Ligament Cells and Gingival Fibroblasts Department of Biochemistry, Nihon University School of Dentistry

O Yoshinori SASAI, Mitsuhiro OHSHIMA, Fumiyuki KUWATA, Naoto SUZUKI, Kichibee OTSUKA, and Kantaro SUZUKI

キーワード：コラゲナーゼインヒビター

歯根膜細胞、歯肉線維芽細胞

\section{[目的 $]$}

培養ヒ卜歯根膜細胞および歯肉線維芽細胞が産生 するコラゲナーゼインヒビターの熱、酵素および薬 剂処理による耐性に差があるかどうかを調べること。

\section{[材料および方法]}

同一歯から得た培趇ヒト歯根膜細胞と歯肉線維芽 細胞とを用いた。第 6 継代目の両細胞をT-75フラ スコで 2 週間培養後、無血清の $\alpha$-MEM と交換し、 5 日間毎日培養上清を回収した。この上清からコラ ゲナーゼインヒビターを硫安分画し、沈渣をbuffer に溶解して透析した後、ACA54ゲル濾過、ヘパリンセ ファロース、イオン交換クロマトグラフィーの順で 粗精製した。各stepごとにコラゲナーゼインヒビタ 一アッセイを行ない、イオン交換クロマト後のピー クを取り出して、耐性試験のためのsampleとした。 このsamplek、熱 $\left(60^{\circ} \mathrm{C} \cdot 95^{\circ} \mathrm{C}\right) \cdot$ 酵素 (Trypsin) - 薬剂 (APMA・DTT) 処理を施した後、インヒビター アッセイを行ないその耐性を調べた。

コラゲナーゼインヒビター活性測定は、FITC標識 コラーゲンを用いた NAGAI らの方法を改良して行な った。また、SDS-PAGE後の銀染色でsampleの精製度 を調べるとともに、市販のウシ歯髄の抗TIMP抗体を 用いた Western・blot 法により、TIMPとの異同も調 ベた。

\section{[結果]}

培養ヒ卜歯根膜細胞及び菌肉線維芽細胞由来のコ ラーゲナーゼインヒビターは、DTT処理で失活し、そ の他の処理ではあまり影響を受けなかった。また、 sampleは単一bandとして認められ、TIMP とむ免疫学
的に交差することがわかった。

各程処理によるコラゲナーせインヒビターの形性（\%）

\begin{tabular}{|c|c|c|}
\hline 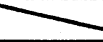 & 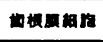 & 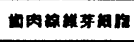 \\
\hline $60^{\circ} \mathrm{C}$ & 100 & 100 \\
\hline $95^{\circ} \mathrm{C}$ & 100 & 100 \\
\hline Trypsin & 77.5 & 82.8 \\
\hline APMA & 90.8 & 94.1 \\
\hline DTT & 0 & 0 \\
\hline
\end{tabular}

\section{[考察]}

歯肉炎・歯周炎は、組織のコラーゲン代謝が分解 系に傾いた結果であるという視点でとらえると、歯 肉炎には䍜患しやすいが、歯周炎にはすぐには移行 しない理由として、歯肉及び歯根膜細胞の産生する コラーゲナーゼやコラーゲナーゼインヒビターの量 的な差、あるいはコラーゲナーゼインヒビターの性 質の差による事などが考えられる。今回妨、両細胞 の産生するコラゲナーゼインヒビターの性質に差が あるのではないかと考え、実験を行なった。その結 果、両細胞の産生するコラーグナーゼインヒビター には耐性の差がほとんどなかったことから、歯肉炎 から歯周炎への移行には、コラーグナーゼやコラー ゲナーゼインヒビターの量的な差が関与している可 能性が示唆された。

\section{[結論]}

培養ヒト歯根膜細胞及び歯肉線維芽細胞の産生す るコラーゲナーゼインヒビターはとむに DTT処理で 失活し、熱 $\left(60^{\circ} \mathrm{C} \cdot 95^{\circ} \mathrm{C}\right) \cdot$ 酔素 (Trypsin) ・薬剂 (APMA）処理ではあまり影響を受けなかった。また、 TIMP とも免疫学的に交差した。 


\begin{abstract}
ヒト歯肉線維芽細胞にお
炎症性サイトカインの影
愛知学院大学歯学部齿就病 野口俊英 Fibroblasts. Aichi-Gakuin University

キーワード：炎症性サイトカイン コラゲナーゼ

T I M P ヒト歯肉線維芽細胞

目的:

コラーゲンやプロテオグリカンが主体を占める歯 周組織の破壊にはコラゲナーゼを中心とするマトリ ックスメタロプロテアーゼ(MMP) が主役を演じてい ることはよく知られている。近年、これらMMP の共 通のインヒビターとしてのtissue inhibitor of metalloproteinases (TIMP) の存在が注目され、実際 の組織破壊では、これらMMP とTIMPのバランスが重 要であることが明らかにされてきた。炎症における これらMMP とTIMPは、マクロファージや好中球のよ うな炎症性細胞によって直接産生・分泌される場合 と、マクロファージを主体とする炎症性細胞が産生 する一連の炎症性サイトカインによって歯肉線維芽 細胞が刺激されて産生・分泌される場合があるが、 歯周組織の破壊にはこれらの因子が複雑に関与して いることが考えられる。本研究では、IL-1を中心と する炎症性サイトカインが歯肉線維芽細胞のコラゲ ナーゼとTIMPの産生に与える影響について検索した ので報告する。
\end{abstract}

教室、生室*

Effects of Inflammatory Cytokines on the Production of Collagenase and Tissue Inhibitor of Metalloproteinases(TIMP) by Human Gingival

Departments of Periodontology and Biochemistry*,School of Dentistry,

OMasaki SAWA, Kyoko YAMASHITA*, Tomohisa MIYASHITA, Hirohisa HAYAKAWA Kaoru OHWAKI , Taro HAYAKAWA* and Toshihide NOGUCHI

\section{材料と方法：}

ヒト歯肉線維芽細胞 (Gin-1細胞) は10\% FCS-DMEM (GIBC0) 中で $5 \% \mathrm{CO}_{2} 、 37^{\circ} \mathrm{C}$ 条件下で培養した。 confluent に達した後、無血清DMEMに交換し、24 時間培養後、再び無血清DMEMに交換後、IL-1は、 $5-500 \mathrm{pg} / \mathrm{ml} 、 \mathrm{TNF}-\alpha$ は1-100ng/m1の濃度になるよう にして培地に加え48時間培養した。回収した培養液 について、TIMPはサンドイッチ醉素免疫測定法 " により、またコラゲナーゼ活性は抗TIMPーモノクロ ナル抗体アフィニティーカラム2) 2 TIMPを除去し

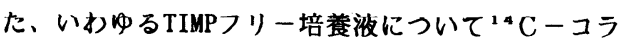
一ゲンを基質とした溶液法 ${ }^{3}$ で測定した。さらに DNA の定量は、Hinegardner の方法“行った。
結果 :

Gin-1細胞の培養液を濃縮後、直接コラゲナーゼ 活性を測定した場合には、APMAによる活性化処理を しても活性は検出されなかった。しかし、モノクロ ナル抗体アフィニティーカラムを通してTIMPを除去 すると、そのままで活性が検出され、さらにAPMA処 理によって、4 倍以上にも活性が上昇することが明 らかとなった。ついで、IL-1のコラゲナーゼおよび TIMP産生に対する影響を検討したところIL-1 $\alpha, \beta$ ともにプロおよび活性型コラゲナーゼの産生を有意 に促進した。またTIMPの産生は、促進される傾向が 認められた。ついで、TNF- $\alpha$ について検討した結 果、濃度依存的にコラゲナーゼ産生を促進したが、 TIMPの産生に関しては、反対に有意な抑制が認めら れた。

\section{考察と結論 :}

IL-1、TNF- $\alpha$ のコラゲナーゼ産生促進作用につい ては、これまでの 2 〜 の報告と一致した結果が得 られた。本研究ではTIMPフリーの試料について検討 した結果、歯周組織破壊に直接関与する活性型コラ ゲナーゼの発現を確認できたこと、およびIL-1、 TNF- $\alpha$ いずれの場合もコラゲナーゼとTIMPのバラン スがコラーゲン分解系へと傾斜する結果を得た。こ れらの結果は、歯周疾患の病因や病態を知る上で興 味ある知見と思われる。

\section{参考文献 :}

1) Kodama et al.J Immunol Methods $127 \quad 1031990$

2) Kodama et al.Collagen Rel Res $\underline{7} 3411987$

3) Terato et al. Biochim Biophys Acta $\underline{445} 753$ 1976

4) Hinegardner et al.Anal Biochem $\underline{39} 197 \quad 1971$ 
歯肉線維芽細胞のIFN $\gamma$ 依存性免度抑制㙨能に関する研究

大阪大学歯学部口沿治療学講座

○島袋善夫 村上伸也 佐保輝之 岡田宏

Study of immunomosupressive function of human gingival fibroblasts

Department of Periodontology and Endodontology, 0saka University Faculty of Dentistry

OYoshio SHIMABUKURO, Shinya MURAKAMI, Teruyuki SAHO, Hiroshi OKADA

キーワード：歯肉線維芽細胞、IFN $\gamma$ 、免疫抑制

研究目的

我々は、Interferon $\gamma$ (IFN $\gamma$ ) 処理した歯肉線維芽細胞 (GFB)がHLA-DR抗原を発現しているにもかかわらず抗原提 示細胞としてアロT細胞を刺激できず、むしろ同GFB自身 が免疫抑制的に働いていることを第 $31 、 32 、 33$ 回 秋季日本歯周病学会において報告した。

今回我々は、さらにPhytohemagglutinin(PHA)刺激によ るT細胞増殖反応を利用し、このIFN $\gamma$ 処理したGFBの免度 抑制効果の発現のメカニズムについて検討を加えた。

\section{材料と方法}

健常者の辺縁歯肉から採取した歯肉片よりout growth させた細胞をGFBとして継代培養し実験に供した。培養は 10\%FCSを含む $\alpha$-modification of Eagles's Medium( $\alpha M$ EM)を用い、実験には5-15代継代した細胞を用いた。GFB をIFN $\gamma$ を含むあるいは含まない $10 \% F C S$ 加 $\alpha$ MEMで 6 日間 培養してその培養上清を回収し、一方これらGFBは $0.05 \%$ Trypsin-EDTAで細胞浮遊液とした後マイトマイシン C 処 理して洗浄後、以下の実験に供した。

Percollを用いた比重遠心法にて健常人末梅血より単 核球を分離した。これを羊赤血球とロぜット形成させ、 ロゼット形成細胞は赤血球除去用トリス緩衝液で羊赤血 球を溶血させ、洗浄後T細胞として用いた。

$1 \times 10^{5}$ 個の T細胞をPHA存在下で、GFBあるいはIFN $\gamma$ 処 理したGFBとともに96穴の丸底マイクロカルチャープレー ト中で 3 日間培養した。

また一部の実験では24穴のカルチャープレート中に組 織培養用透過性コラーゲン膜装置 (高研社製) を置き、 透過膜を介してGFBとT細胞が直接接触しない条件で培養 した。
培養は10\%FCSを含むRPMI 1640培地を用い、37度、5\%C $\mathrm{O}_{2}$ を含む空気中で行っだ。培養終了 6 時間前に $18.5 \mathrm{KBq}$ の トリチウムチミジンを各ウエルに加え培養終了後回収し た細胞の放射活性を液体シンチレーションカウンターで 測定した。

結果

IFN $\gamma$ 処理したGFBはPHA刺激によるT細胞の増殖反応を 抑制した。この抑制効果はIndomethacinの添加によって も部分的にしか回復しなかった。IFN $\gamma$ 処理したGFBによ るT細胞抑制時の培養上清を添加することにより、T細胞 の增殖反応はIFN $\gamma$ 処理されたGFB存在下で検出された抑 制効果に比しごくわずかに抑制された。一方Indomethac in仔在ドで敬整された培食上清を添加した埸合には、T紉 胞の增殖反応は抑制されなかった。

透過性コラーゲン膜によりT細胞とGFBが直接接触しな い条件下で、これらの細胞を同一ウエル内で培養した場 合のT細胞增殖反応は、わずかに抑制された。 考察及び結論

IFN $\gamma$ 処理したGFBはPHA刺激によるT細胞の增殖反応を 抑制した。このIFN $\gamma$ 依存性の抑制効果はIndomethacinの 添加により部分的に解除されること、その培養上清が抑 制効果を持つことからPGE2の関与が考えられた。培養上 清による抑制効果はIndomethacinの添加により完全に阻 害されることからその他の液性因子の関与は考えがたい と思われる。IFN $\gamma$ 処理によりGFBからのPGE2産生が增強 されないことからPGE2による抑制効果はむしろIFN $\gamma$ 非依 存性と考えられる。T細胞とIFN $\gamma$ 処理GFBの細胞接触があ ると抑制が増すことから GFBはT細胞と直接接触すること により IFN $\gamma$ 依存的にその抑制効果を発現するすのと考え られる。 
演題 B-11-1100

ヒト歯根膜線維芽細胞 (HPLF)の細胞接着因子について（第 2 報）

神奈川歯科大学口腔生化学教室

○川瀨俊夫、久保繁樹、佐藤寿之、網野省三、西山勝弘、斎藤滋

Cell Attachment Factors of Human Periodontal Ligament Fibroblast-like Cells (HPLF)

Department of 0ral Biochemistry, Kanagawa Dental College

OToshio Kawase, Shigeki Kubo, Toshiyuki Sato, Shozo Amino, Katsuhiro Nishiyama and Shigeru Saito

キーワード : ヒト齒根膜線維芽細胞、細胞接着因子、 ALPase、細胞增殖因子

[目的］：歯根膜は咀翲と咬合による機械的外力を間歇 的に受ける結合組織であり、機械的外力に対応してRemodelingさらに歯周疾患治虑のRegenerationにおいても 重要である。そこで、HPLF由来の細胞接着因子の特徵に ついてArg·Gly·Asp (RGD) 配列との関係、分子量分布さら に、細胞分化能に関して検索した。

[方法］：HPLFを $1.8 \times 10^{4} \mathrm{cells} / \mathrm{cm}^{2}$ の細胞密度で inoculate し、5\% FCS， $50 \mu \mathrm{g} / \mathrm{ml}$ アスコルビン酸を含む D-MEM で培養し、confluent に達すると、FCS-freeの MCDB107 培地で交換した。さらに24時間培養し、培養上 清を得て、HPLFのconditioned medium(HPLF-CM) とし た。この HPLF-CMを限外口過 (YM-5) で灙縮し、GPC 系の P0-60Kカラムでゲルロ過し、8 分画に分けた。 HPLF-CM,

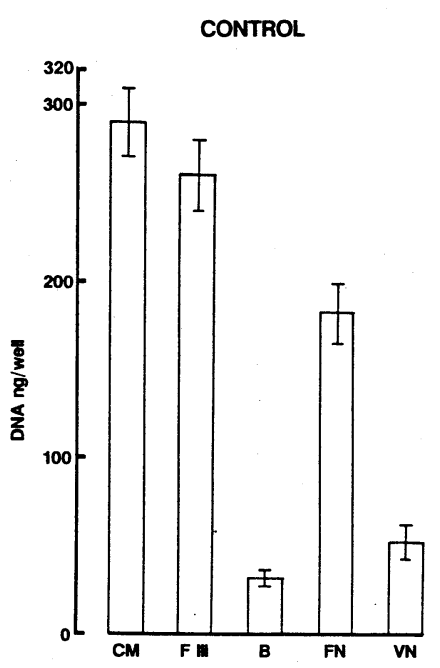

分画したCM, Fibronectin(FN) とVitronectin(VN) を hydrophobic 96 multi-well plate にコーテングし、 heat-inactivated BSAで処理した。一方、GRGDS ペプチ ドとHPLFを 20 分間 $37^{\circ} \mathrm{C}$ で incubateした後、wellにinoculateし、培養後、DNA 量の分析を行い、細胞接着の指標 とした。さらに、HPLFを24時間培養後、HPLF-CM と分画 した CM を 2 回添加し、5 日間培養後、ALPase活性と DNA 量の測定を行った。

[結果および考察］：HPLF-CM, 分画CMをHPLFに添加する と明らかに $5 \sim 60 \mathrm{KDa}$ の FIII りのALPaseの活性が上昇した。しかし、FIII細胞を増 殖活性は認められなかった。 細胞接着・伸展活性は HPLF-CM の分画のうち、活性の高い FIII と $10 \mathrm{KDa}$ の FVI に認められた。Fig に示すことく、HPLF-CM と FIIIは明 らかにFNとVNより活性は高く、GRGDS ペプチド処理によ ク FNとVN共に約29\% まで低下した。一方、HPLF-CM と FIIIにおいてはGRGDS ペプチドにより各々 $63.4 \%$ と 68.5 \% となり約 $35 \%$ のみ阻害された。このことから、HPLFの Integrin family であるFNとVNレセプターは阻害されて いることになる。従って、HPLF-CM の FIII 中にはRGD 配 列の細胞接着シグナルによらない分子種の存在が示唆さ れた。 
演題 B-12-1120

\section{ヒトセメント質由来細胞成長因子が細胞移動に与える影蠁について 大阪菌科大学菌周病学講座}

O松本利一、西村和晃、重山洋一郎、野口吉廣、林正純、山岡 昭

Effect of precementum-derived growth factor incorporation into collagen matrices on fibroblasts migration

Department of Periodontology,0saka Dental University

OToshikazu MATSUMOTO, Kazuaki NISHIMURA, Yoichiro Shigeyana

Yoshihiro Noguchi, Masazumi HAYASHI, Akira YAMAOKA

キーワード : プレセメタム由来細胞成長因子、 細胞移動、コラーゲンマトリックス

目的

近年、緗胞成長因子 (CGF)の緗腺生物学的役割が次第 に明らかになりつつある。我々の領域でも、CGF の甫肉 制離提爬手術後の新結合組蜼性付着成就に果たす役割が 注目されている。とりわけセメント質関連のCGF が創偟 部耕脆の增殖、分化、移動にどのような影暨を与えるか について興味が集中している。我々も、ヒトプレセメン 卜質由来物筫(PCCGF) が或肉由来線維芽緗胞に对してど のような作用を及ぼすかを調べた。その結果、プレセメ ンタム内物質がそれら細胞に対して强力なchemoattractantとして嘢くことを示した。今回は、このPCCGF のコ ラーゲンゲルへの添加が、線維节緗㥸のコラーゲンゲル 内への侵入、移動に与える影隌について䀣知のCGF と比 較、検討した。

\section{材料と方法}

1. collagen gelへの添加物

ヒトプレセメンタムを得るため、矯正的理由により抜 去され、冷凍保存されていた箱20本を使用した。プレセ メンタムは、解凍後、キュレットで强伋採取された。得 たプレセメンタムは、直ちに PBS (-) 2cc の入つた試 䮦管に注入、蛋白成分溶出のためVoltexで数分間层涪後、 $0.22 \mu$ メンブランフィルターで不溶物を除去し、その祲 液を HPLC装置を使用してゲル虑遇 (TSK・G3000)で分画 した。その結果、2つのピークが認められたが、今回は、 分子量 7〜8万のところに溶出された分画 (Fraction 33) をPCCGF といて用いた。他に用いたCGF は PDGF

(Collaborative Research Inc.) 、TGF- $\beta$ (キンク能造 社).FN (岩城硝子社) である。 コラーゲンゲル内に 混入するCGF 量は、各混入CGF の蛋白量を一定にするこ とによって混入量を決定した。すなわちFr.33 の眉白量 は、バイオラッドプロテインアッセイ法を用いてその蛋 白量を测定した。

2. collagen gelの媩整

使用したcollagen溶波は、Cellmatrix Type I-A（新 田ぜラチン株式会社) である。 collagen gel の調整は、 Dochertyの方法に準じて行なった。ます3.2ml の CellMatrix Type I-A (3.0mg/ml,ph3.0) と0.4ml の10 X Eagle's HEM とを 4 'Cにて混合した。その混合液の生理 的なpHおよびイオン强度を媩整するため0.4ml の再棰成

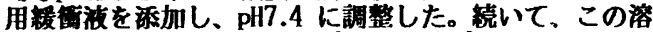
液に、添加CGF の紷蛋白量が200ng 並びに300ng となる ようにFr.33、PDGF、TGF- $\beta$ 、FNを添加した。最終的な コラーゲンの浱度は2.0mg/mとした。をして直ちに、コ ラーゲン溶波を 24 well culture plate $に 0.4 \mathrm{ml} / \mathrm{well}$ 入 九、 $37^{\circ} \mathrm{C} 、 5 \% \mathrm{CO}_{2}-95 \%$ airの湿㳟境下で 30 分間 $\mathrm{incu}^{-}$ bateし、コラーゲンを重合した。

\section{3. 培養細胞侵入度並びに侵入数の分析}

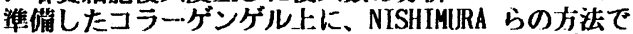

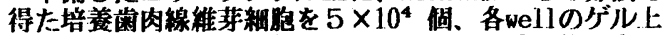
に播種し、開放系で培養した。24、48、72時間後に各 wellの試料を $1 / 2$ Karnovsky 液にて 3 時間的固定し

0.1M Sodium Cacodylate buffer にて一晚浸漬した。浸

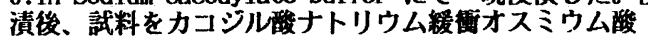
(pH7.2、4 $\left.{ }^{\circ} \mathrm{C}\right)$ にて30分間後固定し、上昇ェタノール系 列にて脱水。その後uft法に従ってEpon 812に包埋し、 半超潦切片を作成、トルイジンブルーにて染色を施した。 そして各試料 1 well から5切片を無作為に選抧し、光

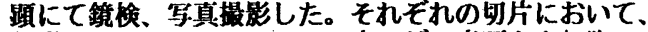
任意の high power field 内でゲル表面から湅胞の leading front までの最長距醀およびゲル内に侵入して

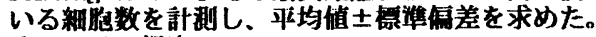

4. TEM钼祭

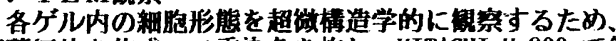
超薄切片を作成、江重染色を施し、HITACHI-H 800 で鏡 倹、䇶察した。

結果

TEM所見：24時間後では，Fr.34 混入ゲル群をは じめとする全ての群で細胞の澡行がみられた。またここ では、Fr.34、PDGF混入ゲル上の細胞内に発達したmi一 crofilament 束がみられた。48洔間になると各群とも、 一ーERの発達した細胞のさらなる深行がみられた。72時間 後では、各群とも、澡行中の細脆に中間大のフィラメン トが目立ったが、lysosomeの增加も著明であった。

細胞の侵入距離並びに侵入数：侵入距離は、FN以外 各群とも陰性对照のHEM に比べ大きかった。72時間後の

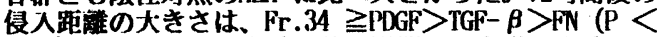
0.01) であった。䖵白量の差の影䇺は、各群、各時間に みられた。すなわち蛋白量 $300 \mathrm{ng}$ 混入群の方が $200 \mathrm{ng}$ 潉 入群上り侵入距矆が大きかった。侵入种能数㤌各群とも、 24時間、48時閒では陰性対照のIFM に対しほとんど差は なかったが、72時間で则に対し差が生じた。各样の侵

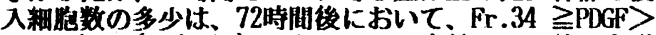
TGF- $\beta>$ FN (P<0.01) であった。䖵白量による差は各群 とも珰められなかった。

考察、結論

セメント筫関連の程々の蛋白が明らかにされつつある。 今回我々がプレセメンタムから部分精盤したFr.34 は。 今回の実呀結果から、今回比較に用いた睡知のCGF に比 ベて、細胞移動に与える影敏は大きいことがかかった。 このことけ、この物質がセメント質での結合斩付着形成 に大きくかかわる可能性を示したことになる。今後今回 使用したこの物贒、あるいはプレセメンタムに含まれる 他の有效物質の同定、精盤の結果を順次発表していくつ もりである。 
牛歯根面に対する培養線維芽細胞の付着に関する研究

日本大学歯学部保存学教室歯周病学講座

戸 戸村真一、吉沼直人、鈴木邦治、岸田修、鄉家英二、江澤庸博、伊藤公一、村井正大

\author{
Attachment of Cultured Fibroblasts to the Bovine Root Surfaces. \\ Department of Periodontology, Nihon University School of Dentistry \\ O Shinichi TOMURA, Naoto YOSHINUMA, Kuniharu SUZUKI, Osamu KISHIDA, \\ Eiji GOKE, Tsunehiro EZAWA, Koichi ITO and Seidai MURAI
}

キーワード：線維芽細胞，セメント質，

\section{付着增殖}

(目的 1

最近の研究では、セメント質を深層まで除 去して歯根面を仕上げる必要性が疑問視され てきている。結合組織性付着による治瘾を期 待した場合、ルートプレーニングによりセメ ント質を残したときと、象牙質まで露出した ときでは何らかの差異が生しることが考えら れる。

今回は細胞培養系を使用し齿根面の質的差 異、すなわち、セメント質と象牙質への培養 線維芽細胞の付着について検討した。

\section{【材料および方法 |}

1.試片の作製

牛下顆切歯を抜去後歯根面に付着している 軟組織を＃15替刃メスで充分に除去した。こ の後齿科用エンジンを用いラバーカップで浮 石末を塗布して低速回転で歯根表面を研磨し 残存軟組織を除去した。また、実体䫓微鏡で 残存軟組織の有無を確認した。

上記のように処理した歯根を歯軸に沿って 中央を椎断後、一方の隣接面から幅 $5 \times 5 \mathrm{~mm}$ 厚 さ3 mmの試片を切り出してメント質群（C群） とした。また、他方の隣接面は表層の $1 \mathrm{~m}$ を 削除して上記同様の研磨を試料に施したのち 試片を切り出し象牙質群（D群）とした。

なお、試片切断の前後に厚さ約 $0.3 \mathrm{~mm}$ 薄 切片を切断しておきこれを研磨標本として光 学顕微鏡でセメント質の有無を碓認した。ま た、調整後の試片は表面粗さ測定器でその表 面粗さを测定して、両群の試料の表面粗さが 近似していることを確認した。
2. 細胞

L181マウス由来培養線維芽細胞を使用した。

3. 実験方法

上述のように調整した各試片を6穴培養デ イッシュ内に静置した。ついで、L181細胞の 細胞浮遊液( $2.0 \times 10^{4} / \mathrm{WLL}, 10 \% \mathrm{FBS}+$ E-MEM)を分注し、72 時間培養した後リン 酸綏衝液で洗浄し、常法に従い走查型電子顕 微鏡（SEM）の試料を作製した。これら各試 料の任意の 5 力所をSEM写真撮影し、そこに付 着する細胞数の平均値をその試料の付着細胞 数とした。なお、各群 10 試片について検討を 行った。

\section{| 結果 |}

1. 付着細胞数

C群およびD群の付着細胞数間に有意な差異 はなかった。

\section{2 . 付着形態}

両群ともに、細胞は細胞質突起を長くのば し、良好に付着していた。

\section{【考察および結論】}

最近、セメント質に線維芽細胞の付着、增 殖および運動性を促進する物質があると報告 されているが、今回の実験系では付着面がセ メント質面でも象牙質面でも線維芽細胞の付 着数および付着形㿟は同等であった。しかし、 付着数という指標において差異がみられない が、コラーゲン活性などの他の指標を用いた 場合に差異が生しる可能性があるので今後検 討する予定である。 